\title{
Evaluation of high-resolution surface wind products at global and regional scales
}

\author{
A. Bentamy ${ }^{1,{ }^{*}}$, D. Croize-Fillon ${ }^{1}$, P. Queffeulou ${ }^{1}$, C. Liu $^{2}$, H. Roquet ${ }^{3}$ \\ ${ }^{1}$ Institut Français pour la Recherche et l'Exploitation de la MER (IFREMER). France \\ ${ }^{2}$ University of Reading. United Kingdom \\ ${ }^{3}$ Météo-France. France
}

* Corresponding author : A. Bentamy, Tel: (33) 2982244 12. Fax: (33) 2982245 33, email address : Abderrahim.Bentamy@ifremer.fr

\begin{abstract}
:
High resolution surface wind fields covering the global ocean, estimated from remotely sensed wind data and ECMWF wind analyses, have been available since 2005 with a spatial resolution of $0.25^{\circ}$ in longitude and latitude, and a temporal resolution of $6 \mathrm{~h}$. Their quality is investigated through various comparisons with surface wind vectors from 190 buoys moored in various oceanic basins, from research vessels and from QuikSCAT scatterometer data taken during 2005-2006. The NCEP/NCAR and NCDC blended wind products are also considered. The comparisons performed during JanuaryDecember 2005 show that speeds and directions compare well to in-situ observations, including from moored buoys and ships, as well as to the remotely sensed data. The root-mean-squared differences of the wind speed and direction for the new blended wind data are lower than $2 \mathrm{~m} / \mathrm{s}$ and $30^{\circ}$, respectively. These values are similar to those estimated in the comparisons of hourly buoy measurements and QuikSCAT near real time retrievals. At global scale, it is found that the new products compare well with the wind speed and wind vector components observed by QuikSCAT. No significant dependencies on the QuikSCAT wind speed or on the oceanic region considered are evident.
\end{abstract}




\section{Introduction}

One of the main goals of operational oceanography and particularly of the Marine EnviRonment and Security for the European Area (MERSEA) project (http://www.mersea.eu.org) is to use numerical models to simulate and forecast the oceanic general circulation on various spatial and temporal scales. Several studies indicated the impact of surface wind forcing fields on oceanic model responses.(e.g. Grima et al, 1999; Blank et al, 2005). Typically, ocean models are forced with products from atmospheric operational centers such as wind analyses from the European Centre for Medium-range Weather Forecasts (ECMWF) which are available over the global ocean every 6 hours (00h:00; 06:00; 12h:00; 18h:00 UT). Since August 1991, scatterometers on board satellites provide continuously 10-m surface wind speed and direction for neutral stratification with high spatial resolution varying between $25 \mathrm{~km}$ and $50 \mathrm{~km}$. Due to the irregular scatterometer sampling, the direct use of the retrievals for operational oceanography is rather limited because most of the numerical ocean models require gridded wind fields. A number of efforts have been made to produce spatially and temporally gridded wind fields from scatterometer off-line wind observations (e.g. Bentamy et al., 1996 and 2002a; Pegion et al., 2000). To minimize the "trackiness" effect related to scatterometer sampling over a swath, some methods average observations within prescribed space and time windows. These windows are greater than $300 \mathrm{~km}$ and 24 hours, respectively. Therefore these mapping methods tend to smooth both instrumental errors as well as real geophysical signals such as rapid space-time wind variability. Another limitation of scatterometer wind observations pertains to their applicability for nearshore use, since wind retrievals are generally not available in these areas due to land contamination.

To overcome the limitations of satellite winds for operational use, near real time remotely sensed winds are merged here with operational ECMWF wind analyses over the 
global ocean including nearshore regions. Previous studies have attempted to enhance the spatial and temporal resolutions of gridded wind fields by blending winds from an atmospheric model with radiometer winds (e.g. Atlas et al, 1996), or with scatterometer winds (e.g. Tang and Liu, 1996; Millif et al, 1999; Zhang et al, 2006). In this study, the gridded wind fields are estimated from near real time scatterometer and radiometer data in combination with ECMWF analysis. The remotely sensed winds come from Seawinds scatterometer onboard QuikSCAT and from Special Sensor Microwave imager (SSM/I) onboard Defense Meteorological Satellite Program (DMSP), F13 and F15, respectively. $\mathrm{SSM} / \mathrm{I}$ data from F14 were not used because they were not available in near real time. The resulting gridded wind fields are generated at synoptic times $(00,06,12$, and 18 UTC) with a delay of 24 hours. We investigate the accuracy of these new wind fields at global and regional scales and compare them to other existing blended wind fields. First, blended wind fields are compared to buoy wind measurements in several regions. Second, to evaluate the skill with which the blended winds are able to reproduce the remotely sensed wind patterns, they are systematically compared to QuikSCAT retrievals. QuickSCAT winds represent the state of the art in global determination of surface wind vectors from satellite measurements. Comparisons are performed over the global ocean as well as for some specific regions of interest such us selected upwelling regions and the Mediterranean Sea.

\section{Data and method}

The estimation and validation of blended wind products make use of QuikSCAT and SSM/I swath winds, ECMWF wind analysis, and moored buoy data available during the period 2004 - 2006. Details related to data quality control, inter-comparisons, and the objective method used to calculate global blended wind fields are provided in a Mersea report 
(http://www.mersea.eu.org/Documents/WP/WP04 ).

Two QuikSCAT datasets are used in this study. A near real time (hereafter NRT) that is produced by the National Oceanic and Atmospheric Administration (NOAA) mainly for operational use (http://manati.orbit.nesdis.noaa.gov) and an off-line product that is generated and provided by the Jet Propulsion Laboratory (http://podaac.jpl.nasa.gov/). This analysis uses data from the $L 2 a$ product, related to backscatter measurements, and from $L 2 b$ product related to wind vector retrievals. The NRT products are extracted from the Météo-France database. The off-line products are extracted from CERSAT/IFREMER, which is the JPL mirror site for scatterometer data. One of the main differences between the NRT and the offline QuikSCAT products is the spatial resolution of the backscatter coefficient $\left(\sigma^{\circ}\right)$. In NRT products, $\sigma^{\circ}$ is an average of all backscatter coefficients measured by the same beam (foreinner, fore-outer, aft-inner, aft-outer) and located within a given wind vector cell (WVC). In the off-line product, each $\sigma^{\circ}$ is given at its nominal spatial resolution. Both $L 2 b$ products have been calculated using the standard scatterometer method based on the Maximum Likelihood Estimator (MLE) (JPL, 2006). However, the NRT wind direction determination uses forecasts from National Centers for Environmental Prediction (NCEP), whereas off-line wind direction is based on the operational 10-m NCEP nowcast analyses. Another difference between the QuikSCAT wind products is related to rain flagging. In this study, the rain flag developed for near real time blended wind field calculation is used (Bentamy et al, 2007). For the off-line products, the rain flag included in the products is used (JPL, 2006).

The scatterometer retrieval algorithm generally estimates four wind solutions for each wind cell. The ambiguity removal method is then used to select the most probable wind solution. To improve the estimated wind direction, particularly in the middle of the swath 
where the azimuth diversity is quite poor, an algorithm called Direction Interval Retrieval with Threshold Nudging (DIRTH) is also used. It is important to note that since January 2002, NRT QuikSCAT winds are being assimilated into the ECMWF model.

Only SSM/I data from DMSP F13 and F15 are available for this study from January 2005 through August 2006. After the $13^{\text {th }}$ of August 2006, F15 failure date, only SSM/I F13 data are used. NRT SSM/I brightness temperature measurements are provided by MétéoFrance. The $10-\mathrm{m}$ wind speed is estimated from SSM/I brightness temperatures using Bentamy et al. (1999) algorithm. The SSM/I wind speeds are calculated over swaths of 1394 $\mathrm{km}$ width, with a spatial resolution of $25 \mathrm{~km} \times 25 \mathrm{~km}$. Previous studies investigated the accuracies of the retrieved SSM/I winds through comparisons with wind speed and direction measured by moored buoys in several oceanic regions (Bentamy et al. 2002b). The standard error values of SSM/I wind speeds with respect to the buoy winds are less than $2 \mathrm{~m} / \mathrm{s}$. The bias values do not exceed $0.20 \mathrm{~m} / \mathrm{s}$.

QuikSCAT and SSM/I follow sun synchronous orbits. The ascending equatorial times occur approximately at $6 \mathrm{~h}$ am $\pm 30 \mathrm{mn}, 6 \mathrm{~h} 33 \mathrm{pm}$, and $8 \mathrm{~h} 42 \mathrm{pm}$ for QuikSCAT, SSM/I F13, and SSM/I F15 respectively. The corresponding descending equatorial times are $6 \mathrm{~h} \mathrm{pm} \pm$ $30 \mathrm{mn}, 6 \mathrm{~h} 33 \mathrm{am}$, and $8 \mathrm{~h} 42 \mathrm{am}$. The geographical distribution of valid remotely sensed wind is illustrated in Figure 1. It shows the ratio of the mean number of wind speed retrievals from QuikSCAT, SSM/I F13, and SSM/I F15 to the number of oceanic grid points $\left(0.25^{\circ} \times 0.25^{\circ}\right)$ at each latitude during January 2005. As expected the highest values are found between $40^{\circ} \mathrm{S}$ and $60^{\circ} \mathrm{S}$. At these latitudes, more than one observation may be expected for each time epoch. Similar sampling length distributions are found between $40^{\circ} \mathrm{N}$ and $60^{\circ} \mathrm{N}$ for 06 am and $06 \mathrm{pm}$. The lowest observation numbers are found in the equatorial region, where satellite retrievals occur within less than $60 \%$ of total grid points. 
The NWP surface winds used in this study come from the European Centre for Medium-range Weather Forecasts (ECMWF) operational analysis and are extracted from the GODIVA database (http://www.nerc-essc.ac.uk/godiva/). The time resolution of the ECMWF data is four times daily $(00,06,12$ and $18 \mathrm{UTC})$ and come on a regular grid of $0.5^{\circ}$ in longitude and latitude. The ECMWF winds are given at $10 \mathrm{~m}$ above sea level.

The remotely sensed surface winds are estimated at $10 \mathrm{~m}$ height in neutral conditions, while the numerical model winds are provided as $10 \mathrm{~m}$ real winds. Even though the atmospheric boundary layer is almost neutrally stable over the global ocean, atmospheric stability may have an impact on the consistency between scatterometer and ECMWF winds, particularly in regions of strong currents and/or during winter seasons. Using a large number of moored buoy data (see hereafter) the difference between $10 \mathrm{~m}$ winds and the equivalent neutral winds both derived from anemometer wind measurements is investigated. About $78 \%$ of total buoy data are measured in stable conditions. Except some few cases (less than 1\%), most of the difference values are between $-0.5 \mathrm{~m} / \mathrm{s}$ (unstable condition) and $0.5 \mathrm{~m} / \mathrm{s}$ (stable condition). The latter is reached during winter season. These results meet Mears et al (2001) conclusions.

An objective method was developed to create the high-resolution spatial and temporal gridded wind fields over the global oceans. The spatial resolutions in both longitude and latitude are $0.25^{\circ}$ and the temporal resolution is 6 hours. The method is an extension of the kriging method previously used to estimate daily wind fields from only QuikSCAT wind observations. All satellite swath data occurring within 3 hours from 6-hourly ECMWF wind epochs are used. The resulting wind fields are referred to as "IFREMER blended wind fields". The accuracy of the method including the impact of the sampling scheme is discussed by Bentamy et al (2007) for the Mediterranean Sea. 
Two other blended wind fields are considered here as well. One that combines NCEP reanalyses and QuikSCAT winds uses spectral properties of the observed winds to synthesize high-wavenumber winds at times and locations where no observations are available is based on the method described by Millif et al (1999). The other which has a spatial resolution of $0.5^{\circ}$ in longitude and latitude and a temporal resolution of 6-hours (at 00h:00, 06h:00, 12h:00, 18h:00 UT) uses the version 4 of NCEP blended products (ftp ncardata.ucar.edu under datasets/ds744.4/data directory). These products are referred to as NCEP/NCAR wind fields.

The second set of blended wind fields are provided by the National Climate Data Center (NCDC) (http://www.ncdc.noaa.gov/oa/rsad/seawinds.html). They are estimated from NCEP re-analyses (NRA-2); surface winds are from scatterometer and SSM/I wind observations. The blended fields are global with temporal resolution of 6 hours. One can notice that the analyses deal first with wind speed estimation, than with wind direction. The wind direction is from NRA-2 (Zhang et al, 2006)

\section{Local Validation}

\subsection{Buoy Comparisons}

Even though the gridded wind fields are designed to characterize large-scale surface wind features, it is quite common to investigate their accuracy through comprehensive comparisons with moored buoy measurements. However, the comparison results should be considered carefully. Indeed, most buoys used in this study are already assimilated by the numerical models such as ECMWF and NCEP, and as described above, satellite data are not fully independent from numerical model estimates. Furthermore, buoy data are currently used within the calibration and validation of remotely sensed surface winds. More than 190 moored buoys are used: 8 moorings located off the French and English coasts and maintained by 
Météo-France and/or UK Met-Office; 10 buoys provided by Puertos d'El Estado located off shore and near shore of Spain; 96 buoys provided by the National Data Buoy Center $(N D B C)$ and located off and near U.S coasts; 66 buoys of the TAO array located in the equatorial Pacific; and 13 buoys of the PIRATA network located in the equatorial Atlantic. The raw buoy wind speeds are converted to the standard height, 10 meters, using the logarithmic profile and assuming atmospheric neutral stability

Buoy data are collocated in space and time with remotely sensed wind observations and with the gridded wind fields. The spatial and temporal criteria of coincidence for buoy measurements and satellite observations (winds over grid points of QuikSCAT and SSM/I swaths) are $25 \mathrm{~km}$ and $30 \mathrm{~min}$, respectively. For gridded wind field validation purposes the buoy data are 6-hourly averaged and the closest grid point $\left(0.25^{\circ} \times 0.25^{\circ}\right.$ for IFREMER and $\mathrm{NCDC}, 0.50^{\circ} \times 0.50^{\circ}$ for $\left.\mathrm{NCEP} / \mathrm{NCAR}\right)$ from the buoy position is selected.

Table 1 summarizes some statistical parameters characterizing buoy and satellite, near real time QuikSCAT observations, as well as blended wind speed and direction comparisons. It provides bias, root mean square (rms), and standard deviation (std) of the differences between buoy and satellite winds. The agreement between buoy and satellite is characterized by the scalar correlation coefficient for wind speed, and vector correlation for wind direction. The latter varies between -2 and 2. The statistical parameters are estimated for all collocated data including all atmospheric and oceanic conditions. In general, the four satellite winds products compare well with buoy estimates. The wind speed correlation coefficients range from 0.71 (PIRATA and Blended_NCEP/NCAR) to 0.91 (MF-UK and Blended_IFREMER). The rms difference has various values according to buoy network and is high in extra-tropical areas and low in tropical regions. The rms differences related to Blended_IFREMER wind speed estimates are less than $2 \mathrm{~m} / \mathrm{s}$ and exhibit the lowest values except in tropical areas. The mean difference values are about $3 \%$ of buoy mean wind speed estimated from all combining 
buoy data and during the comparison period (January - December 2005). One can notice that the Blended_IFREMER wind speed biases (buoy minus blended) with respect to EPPE and $N D B C$ are positive while they are negative with respect to $M F-U K M F-U K, P I R A T A$, and TAO. QuikSCAT, Blended_NCEP/NCAR and Blended_NCDC exhibit negative biases with respect to the five buoy networks. All EPPE buoys and $54 N D B C$ buoys are located within $75 \mathrm{~km}$ from land. At such locations the satellite observation number is quite poor. Therefore, at the corresponding Blended_IFREMER grid points, the wind speeds and directions are mainly derived from ECMWF analysis (Bentamy et al, 2007). Indeed, buoy and ECMWF bias estimated at the coastal locations (not shown) exhibit similar positive values as Blended_IFREMER. Considering NDBC buoys moored off-shore (distance from land higher than $100 \mathrm{~km}$ ), the wind speed and direction biases are $-0.22 \mathrm{~m} / \mathrm{s}$, and $0^{\circ}$, respectively. These are closer to the QuikSCAT biases. For NDBC off-shore buoys and Blended_IFREMER comparisons, the correlation value increases to 0.93 for wind speed, and 1.81 for wind direction On can notice that wind direction correlation coefficient exceed 1 . Indeed, the three blended wind products have similar behaviors with respect to near-shore and off-shore buoys. For instance, the rms differences between buoy and blended winds are higher near-shore than at off-shore locations. The Blended_IFREMER, Blended_NCEP/NCAR, and Blended_NCDC have $\mathrm{rms}$ difference values of $1.33 \mathrm{~m} / \mathrm{s}, 2.11 \mathrm{~m} / \mathrm{s}$, and $1.31 \mathrm{~m} / \mathrm{s}$ for wind speed, and $22^{\circ}, 35^{\circ}$, and $36^{\circ}$ for wind directions estimated from off-shore comparisons. These values increase to $1.73 \mathrm{~m} / \mathrm{s}, 2.56 \mathrm{~m} / \mathrm{s}$, and $2.10 \mathrm{~m} / \mathrm{s}$ for wind speed, and to $34^{\circ}, 50^{\circ}$, and $47^{\circ}$ for wind direction at near-shore locations.

The results related to TAO and PIRATA comparisons indicate that the correlation coefficients are quite high and exceed 0.70 and 1.16 for wind speed and direction, respectively. (There is something I don't know about correlation for wind direction being greater than 1.0you may have to explain that for others as well.) Blended_NCEP/NCAR wind 
speed have the largest rms $(1.66 \mathrm{~m} / \mathrm{s}$ with respect to $T A O)$, while Blended_NCDC have the largest scatter for wind direction $\left(31^{\circ}\right.$ with respect to TAO). Blended_IFREMER exhibit lower correlations with respect to TAO and PIRATA than to EPPE, $N D B C$, and $M F-U K$. The large number of low wind speeds (more than $20 \%$ of $T A O$ buoy winds are less than $5 \mathrm{~m} / \mathrm{s}$ ), the poor sampling scheme of polar satellites (Figure 1), and the accuracy of ECMWF winds (used as background for Blended IFREMER calculation) are the main reasons of these correlation values found over the tropical areas. Indeed, ECMWF have a positive bias of about $0.40 \mathrm{~m} / \mathrm{s}$ with respect to TAO and PIRATA buoy data, whereas QuikSCAT bias is negative. Furthermore, the difference between QuikSCAT observations and ECMWF wind analysis exhibits a maximum in the tropical regions (see section 4).

\subsection{Ship Comparisons}

Most of moored buoy measurements used to assess the quality of the blended wind fields are not fully independent from ECMWF analyses and from satellite retrievals. Indeed, they are routinely used in the assimilation procedures and in the calibration and validation of the remotely sensed raw data. In this section the quality of Blended_IFREMER winds is checked through comparisons with high quality ship wind data (Smith, 2004). The main idea here is to assess the results obtained from buoy and Blended_IFREMER comparisons (an in depth comparison of ship and blended winds is beyond the scope of this paper). Ship data are available off-line and are independent of the numerical model or the satellite winds. They are derived from research vessels and from select voluntary observing ships. Thse data are available through the Shipboard Automated Meteorological and Oceanographic System (SAMOS). One the main goals of SAMOS is the improvement of meteorological and nearsurface oceanographic observations collected by ship data. For instance, surface winds are provided as true winds (speeds relative to the fixed Earth and directions relative to true north) and are correctly estimated from ship-relative measurements. In particular, the major issue 
related to the impact of the flow distortion is considered and eliminated. More details about SAMOS data and processing are available at (http://samos.coaps.fsu.edu). Using anemometer height, sea surface and air temperatures, and relative humidity, ship winds ate adjusted to a height of $10 \mathrm{~m}$ which is the height used for Blended_IFREMER and ship wind comparisons. The two sources are collocated in space and time based on (Bourassa et al, 2003) approach. More specifically, each available and valid ship observations occurring within a grid point of $0.25^{\circ}$ square (blended grid cell) and 3 hours from epoch time are averaged and considered as 6-hourly averaged ship wind estimates. It is obvious that the ship wind distributions are not uniform in space and time over the grid points and during a 6-hour interval. This may have an impact on the comparison results (Bourassa et al, 2003). For instance, only 19\% of averaged ship data are estimated from raw observations collected during a period exceeding 3 hours over a grid cell. The latter are used for comparison purposes

Figure 2 illustrates the comparison of blended IFREMER and ship observations for both wind speed (Figure 2a) and wind direction (Figure 2b). The ship data used are validated collocations from two ships ATLANTIS and KNORR available during 2006. They cover a wide range of latitudes and oceanic and atmospheric conditions. Figure 2 indicates that most of collocated data are close to the ideal fit line (full black line). The correlation between the Blended_IFREMER and in-situ 6-houly winds is 0.86 and 1.57 (vector correlation) for wind speed and direction, respectively. The rms difference between in-situ and blended wind speeds is $1.76 \mathrm{~m} / \mathrm{s}$. Figure 2a indicates that there is no systematic bias between the two wind speed sources. For wind direction comparisons, the mean and standard deviation of difference between ship and blended data are -6 deg and $25 \mathrm{deg}$, respectively. Excluding ship winds lower than $3 \mathrm{~m} / \mathrm{s}$ reduces slightly the standard deviation value to $21 \mathrm{deg}$. The statistical results characterizing the comparisons between ship and blended winds are of the same order than those derived from buoy and blended comparisons. 


\section{Global QuikSCAT and blended wind comparisons}

In this section, the differences between the blended wind fields and QuikSCAT wind retrievals are investigated. The satellite data are derived from the new reprocessing off-line QuikSCAT L2b products (http://podaac.jpl.nasa.gov/QuikSCAT/). One of the main new features is the flagging of rain contamination. Previous studies used QuikSCAT $L 2 b$ products to assess the quality of various surface wind sources at global or regional scales (e.g. McNoldy et al, 2004; MOSTOVOY et al, 2005; Chelton et al, 2006). Indeed, surface winds retrieved from QuikSCAT measurements represent the state of the art in global wind vector estimations. Therefore, QuikSCAT retrievals are used to assess and evaluate the blended wind vector estimates at global scales. Only validated and no rain contaminated data are used. The main goal of such comparisons is to highlight how the blended analysis retrieves the remotely sensed wind observations. For comparison purposes, QuikSCAT and blended wind speed and direction (or wind vector) are collocated in space and time based on the following procedure: for each blended wind vector estimate, all validated QuikSCAT wind speed and direction values located within $12.5 \mathrm{~km}$ from Blended_IFREMER and Blended_NCDC wind cells $\left(0.25^{\circ}\right.$ spatial resolution) and occurring within 3 hours of analysis epoch time $(00 \mathrm{~h}, 06 \mathrm{~h}, 12 \mathrm{~h}$, 18h) are depicted and arithmetically averaged. A similar collocation procedure is used for QuikSCAT and Blended_NCEP/NCAR and QuikSCAT and ECMWF winds, except that the spatial separation is $25 \mathrm{~km}$. The collocation procedure is performed during 2005 .

Only the results for January and July 2005 are investigated in this section. For instance, the monthly averaged wind fields (not shown) estimated from QuikSCAT retrievals, ECMWF, and blended 6-hourly analyses exhibit similar spatial patterns in terms of wind speed as well as in terms of zonal and meridional components. They provide high easterly 
wind conditions (exceeding $12 \mathrm{~m} / \mathrm{s}$ for wind speed) in latitudes north of $40^{\circ} \mathrm{N}$ in the Atlantic and Pacific Oceans, and south of $40^{\circ} \mathrm{S}$ in the Indian and Pacific oceans. The lowest wind speeds are found in the equatorial regions. The variability patterns are also very similar. The highest values are found north $40^{\circ} \mathrm{N}$ in the Atlantic and Pacific Oceans where the wind variability is nearly 5 times higher than in the tropical area. For instance, the spatial distributions of wind speed gustiness (defined as ratio of rms to mean and providing a measurement of the turbulent amplitude in each grid point) during January 2005 indicate that it is lower than 0.1 and higher than 0.4 in the Atlantic trade wind and northern areas, respectively. The various wind directions exhibit very similar spatial patterns in terms of monthly mean and variability. The calculations of the wind steadiness coefficients (defined as the ratio between the mean vector and the mean scalar wind speed and providing a measurement of persistent wind regimes) from the observations and from 6-hourly analyses indicate that the maximum values (great than 0.90) are located in the inter-tropical areas, whereas the minimum (lower than 0.2) are found in regions located north of $20^{\circ} \mathrm{N}$ in the Atlantic and Pacific oceans, and along $40^{\circ} \mathrm{S}$ and $60^{\circ} \mathrm{S}$.

Figure 3 shows the bias and rms differences between collocated QuikSCAT wind observations and the analyses of wind speed, zonal wind component, and meridional wind component estimated during January 2005. Figure 4 shows the corresponding rms difference patterns. The number of collocated data used to estimate the statistical parameters is homogeneous over the global ocean and highly related to the satellite orbit characteristics. As expected the collocated data number (not shown) has a minimum around 30 in the intertropical area, exceeds 50 in the extra-tropical regions, and reaches 85 in highest latitudes. The overall statistics characterizing QuikSCAT and blended collocated data comparisons indicate that the biases are quite low. Among the three blended wind speed analyses, Blended_IFREMER has the highest bias value $-0.16 \mathrm{~m} / \mathrm{s}$. The 95 percentile of absolute value 
of differences are of $0.62 \mathrm{~m} / \mathrm{s}, 0.64 \mathrm{~m} / \mathrm{s}$, and $0.57 \mathrm{~m} / \mathrm{s}$ for IFREMER, NCEP/NCAR, and NCDC blended wind speeds, respectively. On average, the three blended wind speed products appear to be retrieving accurately QuikSCAT observations. Although the biases of zonal and meridional wind differences are quite low (the maximum bias value among the three blended products is $0.05 \mathrm{~m} / \mathrm{s}$ ), their spatial patterns indicate much more departures from the remotely sensed winds (Figure 3). For instance, the 95 percentile of absolute values of zonal wind component (resp. meridional component) differences are of $0.70 \mathrm{~m} / \mathrm{s}, 0.80 \mathrm{~m} / \mathrm{s}$, and $1.53 \mathrm{~m} / \mathrm{s}$ (resp. $0.56 \mathrm{~m} / \mathrm{s}, 0.77 \mathrm{~m} / \mathrm{s}$, and $1.53 \mathrm{~m} / \mathrm{s}$ ) for IFREMER, NCEP/NCAR, and NCDC products, respectively. Obviously and with respect to the data set used for comparison purposes, NCDC wind components have less good agreement with QuikSCAT retrievals than IFREMER and NCEP/NCAR, which one could possible relate to the NCDC wind direction procedure (Zhang et al, 2006)

The rms difference patterns are shown in Figure 4. In general, the rms differences of the three variables (wind speed, zonal, and meridional components) exhibit low values (lower than $1.80 \mathrm{~m} / \mathrm{s}$ ) over the Atlantic, Pacific and Indian trade wind regions, where the wind is quite steady for a given month. The highest rms values are found at high latitudes and especially north of $40^{\circ} \mathrm{N}$ and south of $40^{\circ} \mathrm{S}$ where surface wind is more variable. At these mid- and high latitudes the rms values are about 1-2m/s for IFREMER and NCDC wind speeds, while for zonal and meridional components they are about $1.5-4 \mathrm{~m} / \mathrm{s}$. Through the three rms patterns, we can notice a band of high rms values located north of the equator in the Atlantic and Pacific oceans and in the Gulf of Guinea. This may be related to a misplacement of the intertropical convergence zone (ITCZ) in the blended wind fields. However, the sampling length of collocated data from QuikSCAT and blended winds is minimum over this band. Some high rms value regions are depicted too and especially for both wind components. For instance, over the northwest of the Atlantic and Pacific oceans (related to the Gulf Stream and 
Kuroshio currents) the rms values of QuikSCAT minus Blended_IFREMER may exceed $2.50 \mathrm{~m} / \mathrm{s}$. Such difference patterns are likely related to the discrepancies between QuikSCAT wind observations and ECMWF wind analysis used as background in the IFREMER blended wind field procedure. One can notice that NCEP/NCAR and NCDC zonal and meridional components have large rms values at high latitudes. For instance, over the Atlantic Ocean Blended_NCEP/NCAR exhibits quite low rms differences (less than $1.50 \mathrm{~m} / \mathrm{s}$ ), except in northern and southern areas. In northwestern region, the rms exceeds $3.5 \mathrm{~m} / \mathrm{s}$ related to high variability of NCEP/NCAR winds which was also depicted through the comparisons with buoy data (section 3). Furthermore, steadiness fields (not shown) confirm the Blended-NCDC wind direction departure. Indeed, its steadiness values are slightly lower than the corresponding values estimated from QuikSCAT observations or from 6-hourly analysis.

Blended wind products are assumed to provide improvements with respect to numerical model estimates and to oceanographic use (http://www.mersea.eu.org/). Therefore, the bias and rms differences between scatterometer observations and ECMWF analyses of wind speed, zonal wind component, and meridional wind component are shown in Figures 3 and 4 (first row). The geographical patterns show high magnitudes compared to QuikSCAT minus Blended_IFREMER patterns. The overall bias between QuikSCAT and ECMWF wind speeds is about $0.40 \mathrm{~m} / \mathrm{s}$. It is higher in regions of strong currents: Gulf Stream in the North Atlantic Ocean, Kuroshio Extension in the North Pacific, Agulhas Return Current in the southwest Indian Ocean, and Antarctic Circumpolar Current in the Southern Ocean. In these regions ECMWF tends to underestimate remotely sensed strong winds (higher than $10 \mathrm{~m} / \mathrm{s}$ ). The corresponding rms differences are large too and they exceed $3 \mathrm{~m} / \mathrm{s}$. These departures may be related to the scatterometer measurement physics. Indeed, scatterometer measure surface wind relative to a moving sea surface, while the numerical model estimates surface winds relative to the solid Earth. Most of bias and rms difference patterns of ECMWF wind speed 
(Figure $3 \mathrm{a}$ and $4 \mathrm{a}$ ) zonal component (Figure $3 \mathrm{~b}$ and $4 \mathrm{~b}$ ), and meridional component (Figure $3 \mathrm{c}$ and $4 \mathrm{c}$ ) are significantly reduced in Blended_IFREMER. As mentioned above, the impact of ECMWF as background winds is significant on the blended wind accuracy. For instance, the comparisons performed during July 2007 (not shown) confirm the good agreement between QuikSCAT and blended winds. The main differences are found in the southern Pacific Ocean (south of $40^{\circ} \mathrm{S}$ ) related to the Antarctic Circumpolar Current and along the upwelling areas located northwest of African and American continents. Such discrepancies are related to those found between QuikSCAT and ECMWF analysis.

The comparisons above show that the main discrepancies between QuikSCAT retrievals and the blended estimates are mainly located in the areas of high or low wind conditions. Therefore, the comparison between the two wind sources is investigated with respect to QuikSCAT retrieved wind conditions. Figure 5 represents the difference between QuikSCAT and blended wind speed (Figure 5a), zonal wind component (Figure 5b), and meridional wind component (Figure 5c) versus scatterometer wind speed estimates using difference acceptance criteria. Wind speed retrievals are binned in $1 \mathrm{~m} / \mathrm{s}$ bins. The shaded areas indicate one standard deviation of QuikSCAT minus blended winds. The mean Wind speed difference behavior is as expected: overestimation and underestimation of blended wind speed at low and high QuikSCAT wind speed, respectively. However, we can notice that the mean difference is within two standard deviations for the whole wind speed conditions, while the sampling length for each $1 \mathrm{~m} / \mathrm{s}$ bin is large (on average is about 2100 with a minimum of 812 for $30 \mathrm{~m} / \mathrm{s}$ bin). Therefore, the mean difference is not statistically different from zero with $95 \%$ confidence interval. The shape of wind component differences is mainly related to the sampling length distribution. For the whole QuikSCAT wind speed retrievals, the mean differences cannot be considered different from zero. Such results are not surprising. Indeed 
the two data sets are not fully independent and the method used to estimate blended wind fields is unbiased.

\section{Regional Comparisons}

In order to further investigate the ability of the blended IFREMER winds to recover scatterometer wind retrievals, comparison results are focused on some specific regions in Figs. 6 and 7. Four regions are considered in this study. The first one is located in the western Mediterranean Sea within Gulf of Lion and limited by $3^{\circ} \mathrm{E}-8^{\circ} \mathrm{E}$ and $36^{\circ} \mathrm{N}-44^{\circ} \mathrm{N}$ (first row in Figs. 6 and 7). The regional wind pattern is mainly northwesterly with some high wind conditions generally associated with Mistral events. This is known to be related to the cold air outbreaks due to influxes of cold air into the Mediterranean sea that usually occur along the northern boundary of the specified area and during winter season. The second through the fourth regions are mostly coastal and located western of Mauritania and Morocco, Namibia, California, respectively (second through fourth rows in Figs. 6 and 7). They are limited by $14^{\circ} \mathrm{W}-18^{\circ} \mathrm{W}$ and $18^{\circ} \mathrm{N}-27^{\circ} \mathrm{N} ; 10^{\circ} \mathrm{E}-20^{\circ} \mathrm{E}$ and $26^{\circ} \mathrm{S}-36^{\circ} \mathrm{S}$; and $120^{\circ} \mathrm{W}-126^{\circ} \mathrm{W}$ and $34^{\circ} \mathrm{N}-42^{\circ} \mathrm{N}$. Over these three regions, the surface winds have quite similar characteristics. They flow predominantly parallel to the coastline, due to region locations at the transition between westerly winds and the trade wind zone close to the coast. The highest wind conditions occur generally during spring and summer, winter and fall, and during fall and summer, for the second, third, and fourth regions, respectively. The spatial and temporal wind patterns lead to the formation of the equatoward eastern boundary currents flowing along the coast, i.e. Canary, Benguela, and California currents. The combination of wind and current patterns are associated with upwelling systems. Several statistical parameters are calculated in order to characterize the regional comparisons between QuikSCAT observations and blended 
IFREMER wind estimates as well as between QuikSCAT retrievals and ECMWF wind analyses. As seen in Table 2, the three sources exhibit quite similar behaviors consistent with the results for the global ocean outlined in the previous section. The highest mean and variability values of surface wind speed are provided by QuikSCAT observations over the four regions. The wind speed bias (QuikSCAT minus blended analysis) ranges from $0.02 \mathrm{~m} / \mathrm{s}$ (West of Namibia) to about $0.30 \mathrm{~m} / \mathrm{s}$ (West of California), while the mean difference between scatterometer and ECMWF analyses ranges from $0.35 \mathrm{~m} / \mathrm{s}$ (West of California) to $0.77 \mathrm{~m} / \mathrm{s}$ (Gulf of Lion). For wind components, the three sources agree in basic structure. For instance, in the Gulf of Lion, zonal and meridional winds are skewed eastward and southward, respectively, related to dominant north-westerly winds of the region. As expected, wind in the western Mauritania and Morocco area is generally north-easterly. The main discrepancies between QuikSCAT observations and both blended and ECMWF analyses are associated with component amplitude and variability. This is true for the whole study period (2005) as well as for each season and region.

The discrepancies between wind observations (QuikSCAT) and analyses (blended; ECMWF) are more pronounced at high wind conditions. These results are confirmed through the examination of high order percentile stating that scatterometer observes more high winds. For instance, the 95 percentile exceeding $12 \mathrm{~m} / \mathrm{s}$ and higher are consistently stronger than blended and ECMWF. Their frequencies estimated over each region and during the study period are about $37 \%, 25 \%, 43 \%$, and $39 \%$, respectively. The frequencies of 95 percentile exceeding $12 \mathrm{~m} / \mathrm{s}$ from blended wind speeds account for $32 \%, 10 \%, 38 \%$, and $28 \%$. For ECMWF, these frequencies decrease to $28 \%, 5 \%, 25 \%$, and $25 \%$. On average, for QuikSCAT high wind speeds the bias between scatterometer and blended ranges between $0.47 \mathrm{~m} / \mathrm{s}$ in the western Namibia region, and $1.35 \mathrm{~m} / \mathrm{s}$ off the coast of California. The bias between QuikSCAT and ECMWF ranges between $1.77 \mathrm{~m} / \mathrm{s}$ in the ocean off western Namibia region, 
and $2.59 \mathrm{~m} / \mathrm{s}$ in the Gulf of Lion. In the latter region, the scatterometer provides many extremely strong winds (95 percentile exceeding $18 \mathrm{~m} / \mathrm{s}$ ) than both analyses. Indeed, it is found that 47 of scatterometer extreme events are between $18 \mathrm{~m} / \mathrm{s}$ and $29 \mathrm{~m} / \mathrm{s}$. Over this wind band, the difference between QuikSCAT and analyses wind speeds is about $0.75 \mathrm{~m} / \mathrm{s}$ for blended winds and reaches $4 \mathrm{~m} / \mathrm{s}$ for ECMWF.

The discrepancies between QuikSCAT wind observations and wind analyses derived from blended and from ECMWF products vary as a function of space and time and consequently of wind conditions. Figures 6 and 7 show the monthly-averaged wind vector fields estimated from collocated QuikSCAT/Blended_IFREMER and QuikSCAT/ECMWF data during January and July, respectively. The minimum number of collocated data per grid point for computing the monthly averaged values is set to 15 . On average the number of data used ranges between 37 and 47 leading to day and night sampling. The three wind sources display the general features of the surface wind vectors in the specified region. It is found that the QuikSCAT and blended wind speed correlations exceed 0.70 over the whole areas and for all periods. For more than $95 \%$ of grid points, the correlation coefficients exceed 0.90 even at nearcoast locations. Using Fisher's test, each coefficient correlation estimated from collocated QuikSCAT and blended wind speeds at each grid point, is compared to the coefficient correlations calculated at grid points located within $1^{\mathrm{o}}$ in longitude and latitude. At more than $96 \%$ of grid points, including nearshore locations, the differences between correlation coefficients are not significant with $95 \%$ significance for the four regions and months. Overall, the wind direction correlations are high and exceed 0.90. The main differences between observations and blended estimates are found in wind speed amplitude. At more than $90 \%$ of grid points, the wind speed bias lies between $-0.5 \mathrm{~m} / \mathrm{s}$ and $1 \mathrm{~m} / \mathrm{s}$. However, higher bias values are found. The latter are mainly positive leading to an underestimation of blended winds. For instance, in the northwest regions of the Mediterranean Sea, the bias exceeds $1 \mathrm{~m} / \mathrm{s}$, 
with a maximum of $2 \mathrm{~m} / \mathrm{s}$ in the winter season. Such departures of blended wind speeds compared to QuikSCAT retrievals are associated with high wind conditions, and with the differences between scatterometer and background wind data. Indeed, for January 2005 the mean difference between QuikSCAT and ECMWF ranges between $2 \mathrm{~m} / \mathrm{s}$ and $3.5 \mathrm{~m} / \mathrm{s}$ in this specific area. The latter is characterized, especially during the winter season, by a strong zonal wind speed gradient due to the mistral. Therefore, the blended wind speed underestimation is associated with model underestimation of the mistral strength. Moreover, at most grid points located near the coast in this region, blended wind estimates are underestimated compared to the scatterometer retrievals. Quite similar results are found west of California showing underestimation of nearshore blended winds except at some grid points in northern locations during July 2005. Obviously, the largest discrepancies between QuikSCAT and blended wind speeds are found in the area located within $1^{\circ}$ of $38^{\circ} \mathrm{N}$ and $125^{\circ} \mathrm{W}$ for July 2005 . They are related to high wind conditions associated with the near coast orographic wind intensification during the summer season. The comparison investigations performed over the second and third regions of interest confirm that the departures of blended wind estimates relative to QuikSCAT winds are mainly related to high wind conditions, and that the former do not involve any systematic spatial or temporal bias.

\section{Summary}

This paper deals with the quality of blended wind fields estimated from remotely sensed wind observations and from atmospheric numerical model analysis. They are routinely calculated based on the use of near real time QuikSCAT and SSM/I wind retrievals as surface wind observations and ECMWF wind analysis as background through an objective method. The resulting blended wind fields are global with a spatial resolution of $0.25^{\circ}$ in longitude and 
latitude and temporal resolution of 6 hours (00h; 06h; 12h; 18h UTC). To assess their quality, they are compared to surface winds from moored buoy in various oceanic areas and from offline QuikSCAT data during 2005. The comparisons are extended to two existing blended products provided by NCEP/NCAR and by NCDC. The main goal of this study is to investigate the ability of the blended winds to reveal the observed surface wind dynamic at local and global scale. This work might not be considered as an accuracy study. Indeed, data used are not fully independent. For instance, most of buoy data and QuikSCAT retrievals are assimilated in the ECMWF model. Furthermore and due to the objective method, the blended wind fields are designed to provide large-scale wind patterns. However, to assess the results derived from Blended_IFREMER and buoy comparisons, the former quality is checked through comparisons with research vessel data during 2006. Despite of collocation issue, the investigation indicates that the rms differences of wind speeds and directions are less than $2 \mathrm{~m} / \mathrm{s}$ and $25 \mathrm{deg}$, respectively, which are of the same order than the characteristics found for buoy and blended comparisons.

The blended wind field quality is estimated through the determination of some statistical parameters characterizing the comparisons with in-situ and remotely sensed wind speeds and direction (or zonal and meridional components). The relatively large amount of observed and analysis winds allows robust statistical comparisons. The results of the matchup data indicate that blended wind speed and direction retrieve the corresponding in-situ as well as QuikSCAT estimates. More specifically, the standard deviations of buoy and Blended_IFREMER wind speed and direction differences do not exceed $1.70 \mathrm{~m} / \mathrm{s}$ and $30^{\circ}$, respectively. The associated correlation coefficients for wind speed and direction are higher than 0.80 and 1.39 , respectively. The best results are found at off-shore buoy locations and are quite similar to QuikSCAT wind performances. In the comparisons with near-coast buoy data (buoy moored less than $70 \mathrm{~km}$ from land) the Blended_IFREMER product exhibit similar 
performances as ECMWF. Through the buoy comparisons, Blended_IFREMER provide the best results compared to the two blended products, except in the tropical area where NCDC blended wind speeds exhibit lower rms differences and higher correlation coefficients.

At global scale, the quality investigations are performed through comparisons with offline QuikSCAT wind retrievals. Some source differences, such as the QuikSCAT random component errors (Chelton et al, 2005), the estimation of remotely sensed winds in neutral condition, and the time and space collocation procedure, may have an impact on the comparison results. However, the remarkable agreement between buoy and QuikSCAT winds allows using the scatterometer data as a surface wind reference. The comparisons with offline QuikSCAT wind observations also indicate that blended wind speed and wind components are in good agreement with the remotely sensed ones.

During January 2005, the overall mean differences between QuikSCAT and Blended_IFREMER are quite low, while the corresponding rms are about $1.10 \mathrm{~m} / \mathrm{s}, 1.65 \mathrm{~m} / \mathrm{s}$, and $1.48 \mathrm{~m} / \mathrm{s}$ for wind speed, zonal wind component, and meridional wind component, respectively. Blended_IFREMER appears to be closer to off-line QuikSCAT wind observations than Blended_NCEP/NCAR and Blended_NCDC, especially in terms of wind components. Furthermore, Blended_IFREMER improves the results obtained from the comparisons between QuikSCAT and ECMWF analyses for both wind speed and wind components. One of the main improvements is the reduction of the positive difference bias between QuikSCAT and ECMWF winds found near the main ocean currents. However, Blended_IFREMER wind speeds are still slightly underestimated compared to QuikSCAT retrievals. It is found that the main discrepancies between QuikSCAT and Blended IFREMER are due to the procedure used to estimate the gridded wind fields. For instance, they are highly associated with the discrepancies between QuikSCAT and ECMWF winds. The procedure would profit from certain improvements including the determination of 
adequate weights for remotely sensed observations and for numerical model analyses. The present method deals only with the weights of the differences between observations and analyses at each satellite wind vector cell.

The results of this study show that the blended wind products may meet the requirements of some scientific projects dealing with the identification of upwelling events (Blank et al, 2005) or with the characterization of wind as a forcing function for a wave model in the Mediterranean sea (Queffeulou et al, 2007). This study describes the temporal and spatial patterns of blended surface wind in some specific regions of interest and how they compare to those derived from QuikSCAT-only wind observations. The results indicate that the two sources exhibit very similar patterns over all regions in terms of wind speed and direction. The most important conclusion is that Blended_IFREMER reduce the difference biases between QuikSCAT and ECMWF in off-shore as well as in near-shore areas. Even though QuikSCAT alone is closer to reality the Blended_IFREMER product provides the convenience of complete coverage at the standard synoptic times and over the global ocean.

Although some improvements are needed to enhance the quality of blended wind estimates, one may conclude that they can be used for investigating mesoscale air-sea interaction processes at global scales as well as in several regions including near-shore areas.

\section{Aknowledgements}

This study is supported by MERSEA project. The authors are grateful to ECMWF, CERSAT, GODIVA, IRD, JPL, Météo-France, NDBC, PMEL, Puertos del Estado for providing the raw data used in this study. We would like to thank the authors of the NCEP/NCAR and NCDC blended wind fields. We thank Dr Kristina Katsaros and Dr Alberto Mestas Nuñez for their helpful comments and suggestions on this manuscript

\section{Data access:}


http://cersat.ifremer.fr/fr/data/discovery/by_product_type/gridded_products/mwf_blended 


\section{References}

Atlas, R., R. Hoffman, S. Bloom, J. Jusem, and J. Ardizzone, 1996: A multi-year global surface wind velocity data set using SSM/I wind observations, Bull. Amer. Meteoro. Soc., 77, 869-882.

1Bentamy, A., Y. Quilfen, F. Gohin, N. Grima, M. Lenaour, and J. Servain, 1996: Determination and validation of average field from ERS-1 scatterometer measurements. Global Atmos. Ocean Sys., 4, 1-29.

Bentamy A, P. Queffeulou, Y. Quilfen and K. Katsaros, 1999 : Ocean surface wind fields estimated from satellite active and passive microwave instruments, IEEE Trans. Geos. Rem. Sens., Vol 37, No 5, 2469-2486.

Bentamy A., Y. Quilfen, and P. Flament, 2002(a): Scatterometer wind fields - a new release over the decade 1991 - 2001. Can. J. Remote Sensing, 28, 3, 431-449

Bentamy A., K B. Katsaros, W. M. Drennan, E. B. Forde, 2002(b): Daily surface wind fields produced by merged satellite data. American Geophys. Union, Geophysical Monograph Series Vol. 127, 343-349.

Bentamy A., H-L Ayina, P. Queffeulou, D. Croize-Fillon ; 2007 : Improved Near Real Time Surface Wind Resolution over The Mediterranean Sea. Ocean Sci., 3, 259-271.

Blanke B., S. Speich, A. Bentamy, C. Roy; B. Sow, 2005 : Modeling the structure and variability of the southern Benguela upwelling using QuikSCAT wind forcing $J$. Geophys. Res., Vol. 110, No. C7, C07018

Bourassa, M. A., D. M. Legler, J. J. O'Brien, and S. R. Smith, 2003: SeaWinds validation with research vessels. Journal of Geophysical Research, 108, DOI 10.1029/2001JC001081, doi:10.1029/2001JC001081. 
Chelton D. B. and M. H. Freilich, 2005: Scatterometer-Based Assessment of 10-m Wind Analyses from the Operational ECMWF and NCEP Numerical Weather Prediction Models. Mon. Weather Rev., Vol 133, pp 409-429.

Chelton D. B, M. H. Freilich, J. M. Sienkiewicz and J. M. Von Ahn, 2006 : On the Use of QuikSCAT Scatterometer Measurements of Surface Winds for Marine Weather Prediction, Month. Weath. Review, Vol 134, pp 2055-2071.

2Grima, N., A. Bentamy, K. Katsaros, and Y. Quilfen, 1999: Sensitivity of an oceanic general circulation model forced by satellite wind stress fields. J. Geophys. Res., 104, 79677989.

JPL, 2006: QuikScat science data product user's manual (version 3.0), Jet Propulsion Laboratory Publ. D-18053, Pasadena, CA, 91 pp.,available online: http://podaac.jpl.nasa.gov/DATA_CATALOG

McNoldy B. D., P. E. Ciesielski, W. H. Schubert, and R. H. Johnson, 2004: Surface winds, divergence, and vorticity in stratocumulus regions using QuikSCAT and reanalysis winds ; Gephys. Res. Lett. , Vol. 31, L08105, doi:10.1029/2004GL019768.

Mears C. A., D. K. Smith, and F. J. Wentz, 2001: Comparison of Special Sensor Microwave Imager and buoy-measured wind speeds from 1987 to 1997, J. Geophys. Res., 106, 11719-11729

Milliff, R. F., W. G. Large, J. Monel, G. Danabasoglua, and T. M. Chin, 1999:Ocean general circulation model sensitivity to forcing from scatterometer winds. J. Geophys Res.,104, $11,337-11,358$.

Mostovoy G. V., P. J. Fitzpatrick.' and Y. Li, 2005 : Regional accuracy of QuikSCAT gridded winds, Int. J. Remote Sens, vol. 26, n¹8, pp. 4117-4136

Pegion, P. J., M. A. Bourassa, D. M. Legler, and J. J. O’Brien, 2000: Objective derived daily “winds" from satellite scatterometer data, Mon. Wea. Rev., 128, 3150-3168. 
Queffeulou P. and A. Bentamy, 2007: Analysis of Wave Height Variability Using Altimeter Measurements: Application to the Mediterranean Sea. J. Atmos Oceanic Technol, Vol. 24, No. 12, pp 2078-2092.

Smith, S. R., 2004: Focusing on improving automated meteorological observations from ships. EOS, Trans Amer. Geophys. Union, 85, 319.

Tang, W., and W. T. Liu, Objective interpolation of scatterometer winds, 1996: JPL Tech. Publication 96-19, 16 pp.

Zhang, H.-M.,J. J. Bates, and R. W. Reynolds , 2006: Assessment of composite global sampling: Sea surface wind speed, Geophys. Res. Lett., 33,L17714, doi:10.1029/2006GL027086. 


\section{Tables}

Table 1: Statistical comparisons of wind speeds and directions derived from collocated buoy QuikSCAT, and blended data.

\begin{tabular}{|c|c|c|c|c|c|c|c|c|}
\hline \multicolumn{3}{|c|}{ 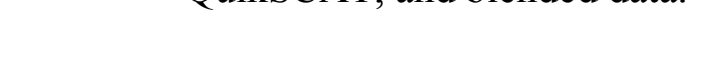 } & \multicolumn{3}{|c|}{ Wind Speed } & \multicolumn{3}{|c|}{ Wind Direction } \\
\hline & & Length & Bias & $\mathrm{Rms}$ & Correlation & Bias & Std & Correlation \\
\hline \multirow{4}{*}{ EPPE } & QuikSCAT & 471 & -0.74 & 1.68 & 0.92 & -5 & 45 & 1.33 \\
\hline & Blended_IFREMER & 4687 & 0.43 & 1.67 & 0.88 & 0 & 37 & 1.50 \\
\hline & Blended_NCEP/NCAR & 4693 & -0.62 & 2.54 & 0.76 & 0 & 48 & 1.18 \\
\hline & Blended_NCDC & 4409 & -0.70 & 1.89 & 0.87 & -5 & 48 & 1.24 \\
\hline \multirow{4}{*}{ NDBC } & QuikSCAT & 6961 & -0.20 & 1.28 & 0.93 & -4 & 30 & 1.72 \\
\hline & Blended_IFREMER & 48543 & 0.13 & 1.58 & 0.88 & -5 & 29 & 1.73 \\
\hline & Blended_NCEP/NCAR & 43234 & -0.31 & 2.36 & 0.77 & -8 & 43 & 1.37 \\
\hline & Blended_NCDC & 44729 & $\overline{-0.44}$ & 1.78 & 0.86 & -7 & 41 & 1.49 \\
\hline \multirow{4}{*}{ MF-UK } & QuikSCAT & 1020 & -0.30 & 1.38 & 0.92 & 1 & 29 & 1.71 \\
\hline & Blended_IFREMER & 5550 & -0.24 & 1.70 & 0.91 & 1 & 23 & 1.75 \\
\hline & Blended_NCEP/NCAR & 5557 & -0.25 & 2.18 & 0.84 & -1 & 36 & 1.49 \\
\hline & Blended_NCDC & 5557 & -0.34 & 2.56 & 0.75 & -1 & 49 & 1.27 \\
\hline \multirow{4}{*}{ PIRATA } & QuikSCAT & 461 & -0.26 & 0.88 & 0.87 & -3 & 14 & 1.33 \\
\hline & Blended_IFREMER & 4242 & -0.47 & 1.27 & 0.80 & -3 & 16 & 1.39 \\
\hline & Blended_NCEP/NCAR & 4246 & -0.25 & 1.49 & 0.71 & -4 & 21 & 1.29 \\
\hline & Blended_NCDC & 4236 & -0.32 & 1.07 & 0.84 & -3 & 27 & 1.16 \\
\hline \multirow{4}{*}{ TAO } & QuikSCAT & 2696 & -0.14 & 0.98 & 0.90 & -4 & 24 & 1.65 \\
\hline & Blended_IFREMER & 33480 & -0.34 & 1.31 & 0.83 & 2 & 20 & 1.65 \\
\hline & Blended_NCEP/NCAR & 33517 & -0.08 & 1.66 & 0.73 & -3 & 25 & 1.45 \\
\hline & Blended_NCDC & 33368 & -0.16 & 1.14 & 0.86 & -2 & 31 & 1.31 \\
\hline
\end{tabular}


Table 2: Mean and standard deviation (between parentheses) of QuikSCAT, Blended_IFREMER, and ECMWF winds estimated over four oceanic areas and during 2005.

\begin{tabular}{|c|l|c|c|c|c|}
\cline { 3 - 6 } \multicolumn{2}{|c|}{} & Gulf of Lion & $\begin{array}{l}\text { W. of Mauritania } \\
\text { and Morocco }\end{array}$ & W. of Namibia & $\begin{array}{l}\text { W. of } \\
\text { California }\end{array}$ \\
\hline \multirow{3}{*}{ Wind Speed (m/s) } & QuikSCAT & $6.87(2.55)$ & $7.94(1.68)$ & $7.88(2.28)$ & $7.61(2.05)$ \\
\cline { 2 - 6 } & Blended & $6.61(2.31)$ & $7.63(1.39)$ & $7.90(2.11)$ & $7.30(1.76)$ \\
\cline { 2 - 6 } & ECMWF & $6.10(2.10)$ & $7.47(1.38)$ & $7.31(1.91)$ & $7.26(1.73)$ \\
\hline \multirow{3}{*}{ Zonal Component (m/s) } & QuikSCAT & $1.30(3.20)$ & $-2.59(1.90)$ & $-0.13(2.64)$ & $2.48(1.73)$ \\
\cline { 2 - 6 } & Blended & $1.16(2.93)$ & $-2.32(1.73)$ & $-0.04(2.59)$ & $2.63(1.42)$ \\
\cline { 2 - 6 } & ECMWF & $1.00(3.06)$ & $-2.09(1.83)$ & $-0.18(2.44)$ & $2.90(1.49)$ \\
\hline \multirow{2}{*}{\begin{tabular}{c} 
Meridional component \\
\multirow{2}{*}{$(\mathbf{m} / \mathbf{s})$}
\end{tabular}} & QuikSCAT & $-2.38(2.56)$ & $-6.06(1.80)$ & $4.35(2.69)$ & $-4.24(2.62)$ \\
\cline { 2 - 6 } & Blended & $-2.40(2.31)$ & $-5.83(1.54)$ & $4.19(2.54)$ & $-3.86(2.34)$ \\
\cline { 2 - 6 } & ECMWF & $-2.14(2.33)$ & $-5.78(1.64)$ & $3.90(2.35)$ & $-4.00(2.34)$ \\
\hline
\end{tabular}




\section{Figures}

Figure 1: Latitudinal behavior of number of satellite wind speed retrievals reported to the number of oceanic grid point $\left(0.25^{\circ} \times 0.25^{\circ}\right)$ for the four-time epoch: $00 \mathrm{~h}: 00$, 06h:00, 12h:00, and 18h:00 UTC.

Figure 2:. Comparison of Blended_IFREMER wind peed (left panel) and wind direction (right panel) with ship -6houly averaged wind estimates. Color indicates data frequency. The inner and outer dashed lines indicate one and tow standard deviation values, respectively

Figure 3 : Monthly bias of wind speed (first column), zonal component (second column), and meridional component (third column), differences between collocated QuikSCAT observations and ECMWF analysis (first row), Blended_IFREMER (second row), Blended_NCEP/NCAR (third row), and Blended_NCDC (Fourth row) estimates during January 2005. Unit is in $\mathrm{m} / \mathrm{s}$

Figure 4 : Monthly rms difference of wind speed (first column), zonal component (second column), and meridional component (third column) differences between collocated QuikSCAT observations and ECMWF analysis (first row), Blended_IFREMER (second row), Blended_NCEP/NCAR (third row), and Blended_NCDC (Fourth row) estimates during January 2005. Unit is in $\mathrm{m} / \mathrm{s}$.

Figure 5 : Difference between QuikSCAT wind observations and blended wind estimates as a function of QuikSCAT wind speed for the period January - March 2005. Heavy lines indicate the mean difference, while the shaded area indicate on standard deviation of QuikSCAT minus blended wind speed (a), zonal component (b), and meridional component (c) 
Figure 6 : Mean wind vector fields for January 2005 estimated from QuikSCAT observations $\left(1^{\text {st }}\right.$ column$)$, Blended_IFREMER $\left(2^{\text {nd }}\right.$ column $)$, and ECMWF analysis $\left(3^{\text {rd }}\right.$ column) over western Mediterranean area ( $1^{\text {st }}$ row), western of Mauritania and Morocco area ( $2^{\text {nd }}$ row), Namibia area ( $3^{\text {rd }}$ row), and over California area ( $4^{\text {th }}$ row). The color contours indicates wind speed ranges and the arrows indicate wind direction. The latter are reported every $0.5^{\circ}$ in longitude and latitude.

Figure 7 : As Figure 6 for July 2005 


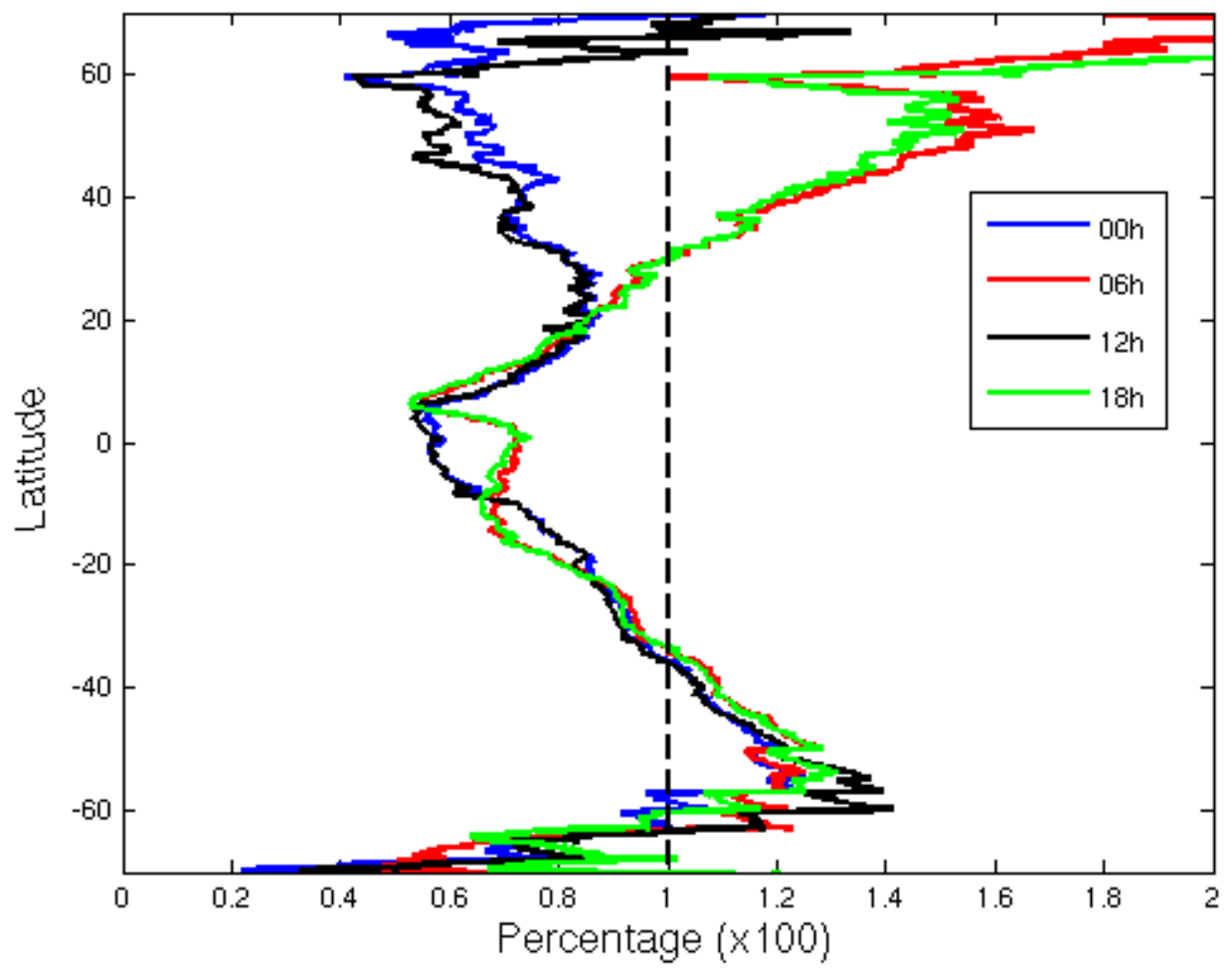

Figure 1: Latitudinal behavior of number of satellite wind speed retrievals reported to the number of oceanic grid point $\left(0.25^{\circ} \times 0.25^{\circ}\right)$ for the four-time epoch: 00h:00, 06h:00, 12h:00, and 18h:00 UTC. 

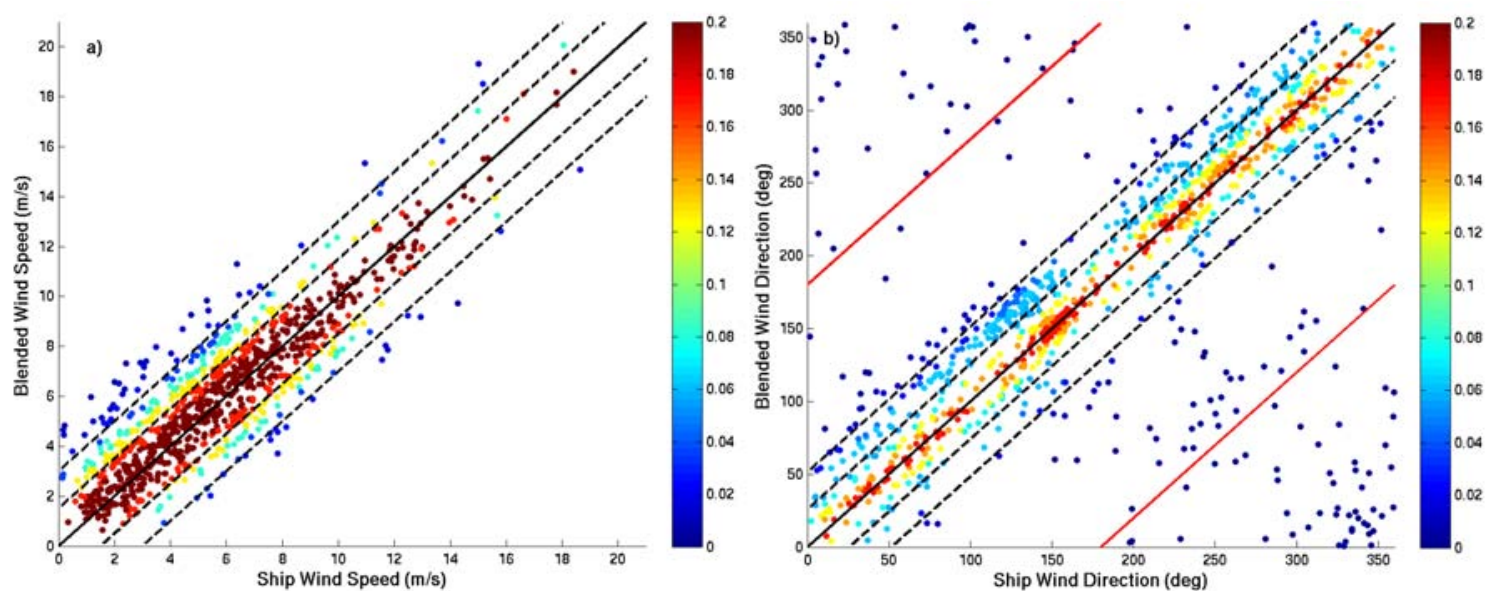

Figure 2 : Comparison of Blended_IFREMER wind peed (left panel) and wind direction

(right panel) with ship -6houly averaged wind estimates. Color indicates data frequency. The inner and outer dashed lines indicate one and tow standard deviation values, respectively. 


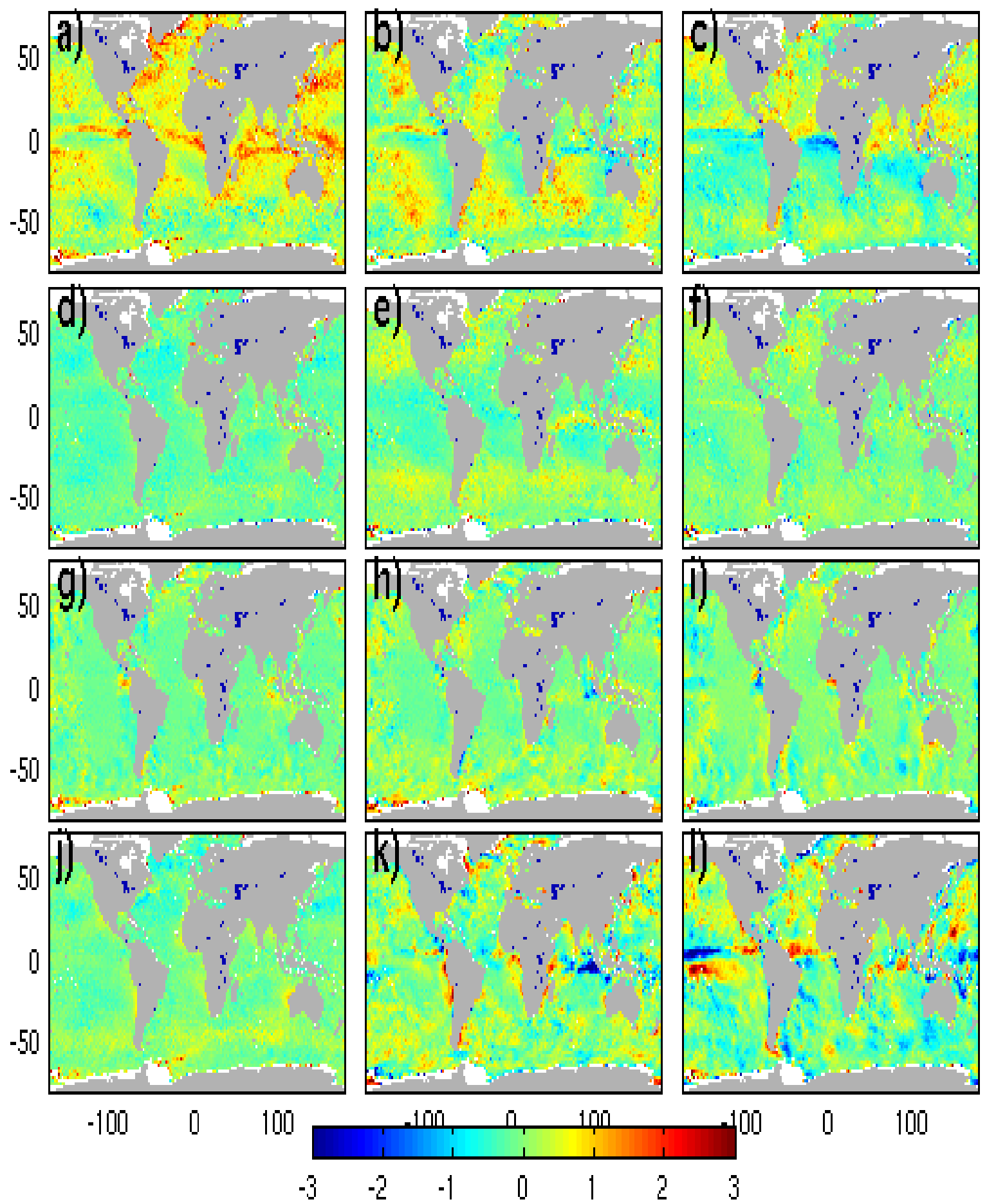

Figure 3 : Monthly bias of wind speed (first column), zonal component (second column), and meridional component (third column) differences between collocated QuikSCAT observations and ECMWF analysis (first row), Blended_IFREMER (second row), Blended_NCEP/NCAR (third row), and Blended_NCDC (Fourth row) estimates during January 2005. Unit is in $\mathrm{m} / \mathrm{s}$ 

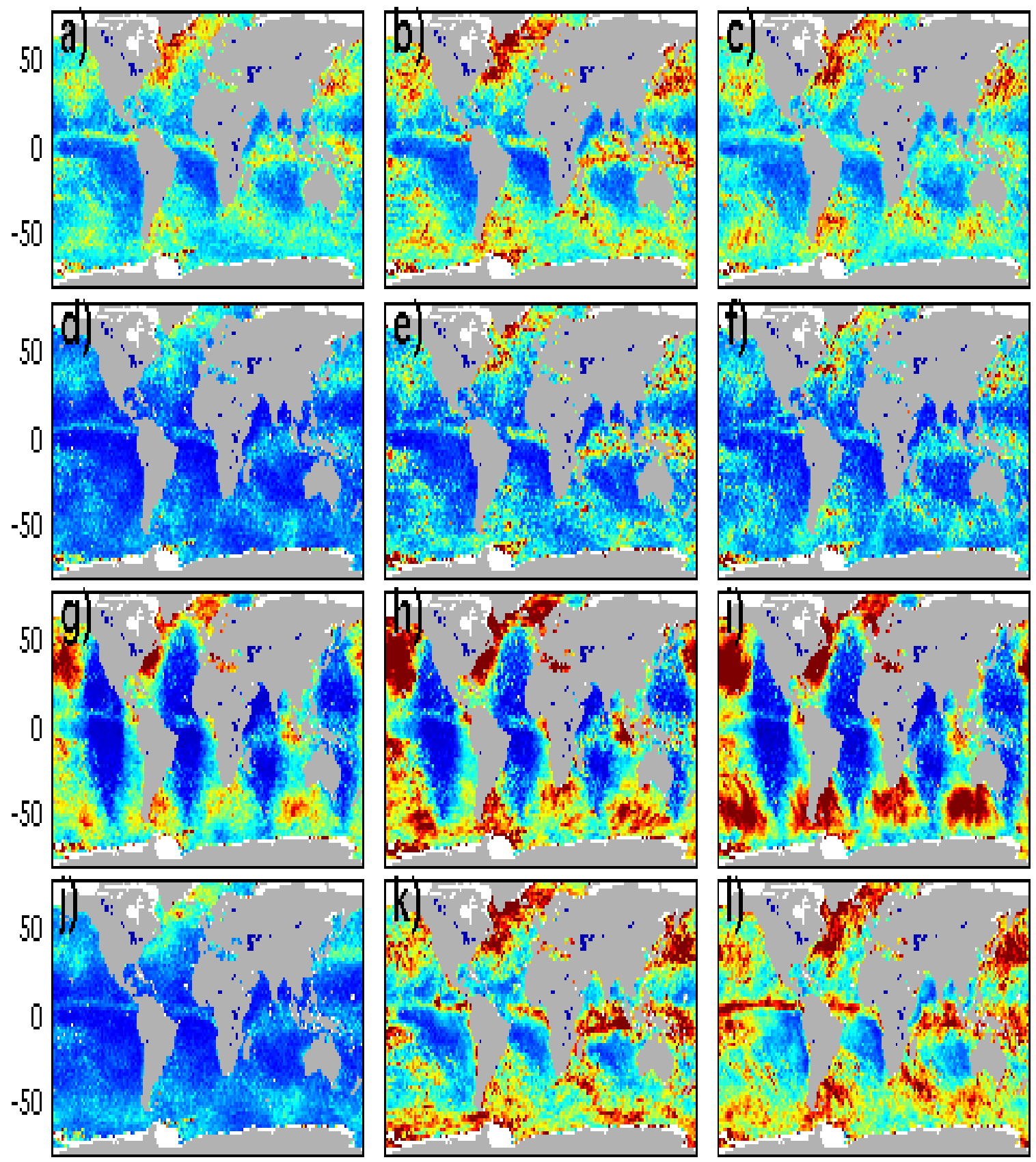

- 1000100100

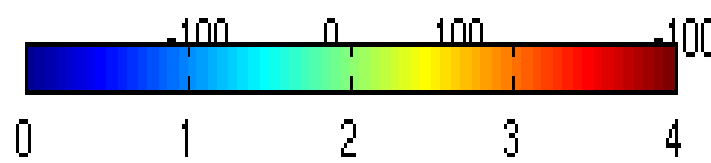

(1) 1010

Figure 4 : Monthly rms difference of wind speed (first column), zonal component (second column), and meridional component (third column) differences between collocated QuikSCAT observations and ECMWF analysis (first row), Blended_IFREMER (second row), Blended_NCEP/NCAR (third row), and Blended_NCDC (Fourth row) estimates during January 2005. Unit is in m/s. 


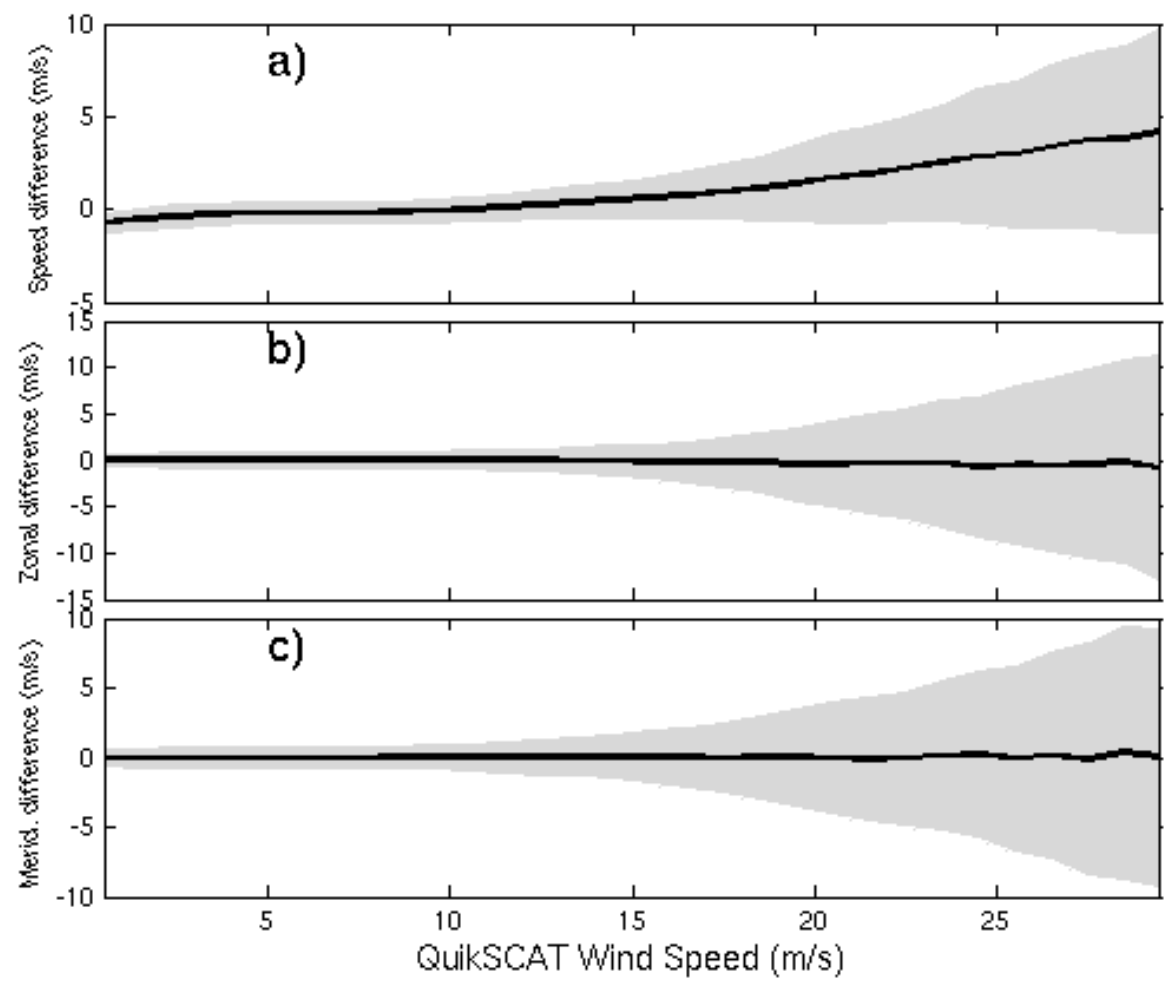

Figure 5 : Difference between QuikSCAT wind observations and blended wind estimates as a function of QuikSCAT wind speed for the period January - March 2005. Heavy lines indicate the mean difference, while the shaded area indicate on standard deviation of QuikSCAT minus blended wind speed (a), zonal component (b), and meridional component (c) 

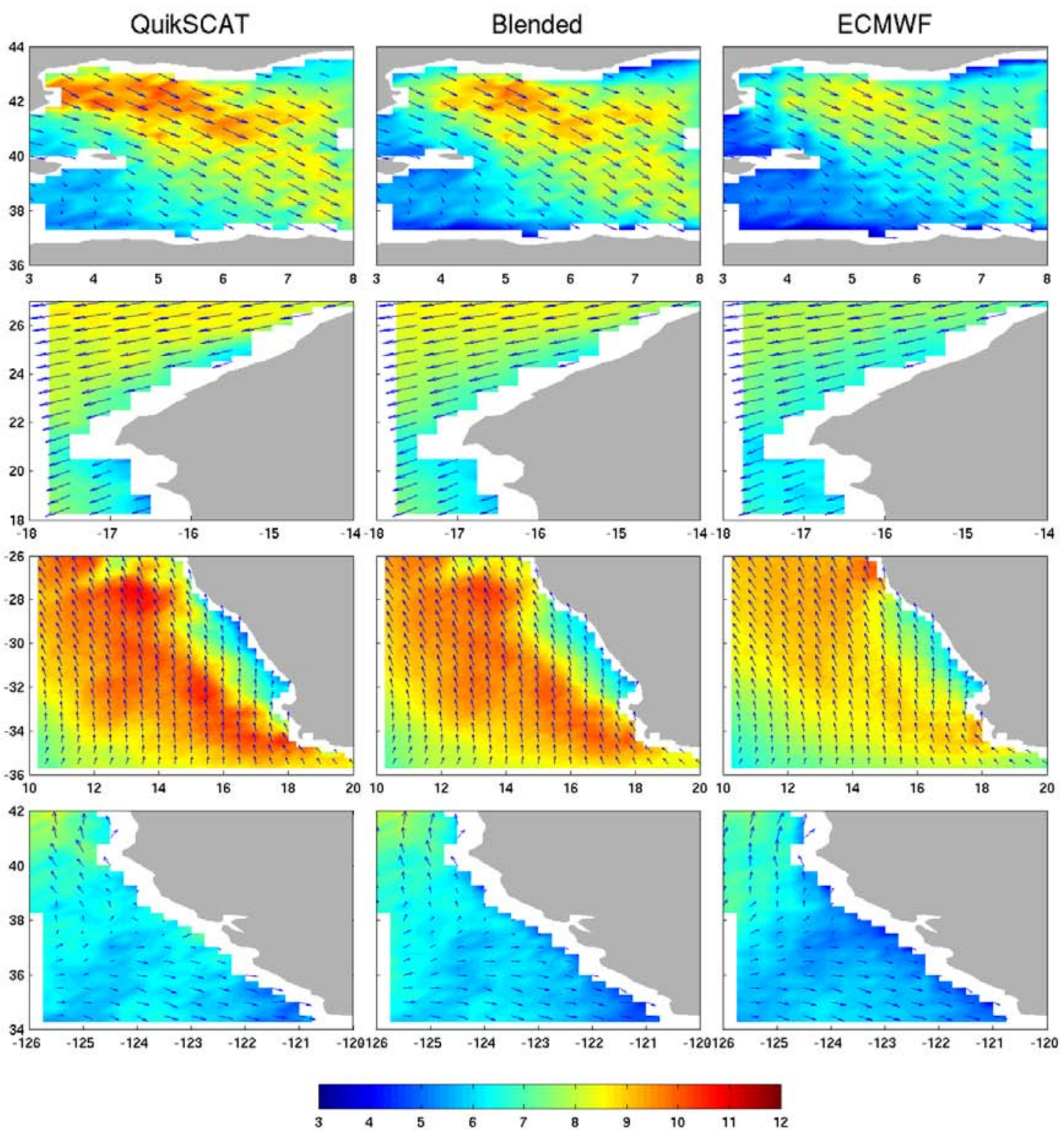

Figure 6: Mean wind vector for January 2005 estimated from QuikSCAT observations $\left(1^{\text {st }}\right.$ column), Blended_IFREMER ( nd $^{\text {nd }}$ column), and from ECMWF analysis $\left(3^{\text {rd }}\right.$ column) over western Mediterranean area ( $1^{\text {st }}$ row), western of Mauritania and Morocco area ( $2^{\text {nd }}$ row), Namibia area ( $3^{\text {rd }}$ row), and over California area ( $4^{\text {th }}$ row). Colour indicates wind speed ranges, while arrows indicate wind direction. The latter are reported every $0.5^{\circ}$ in longitude and latitude. 

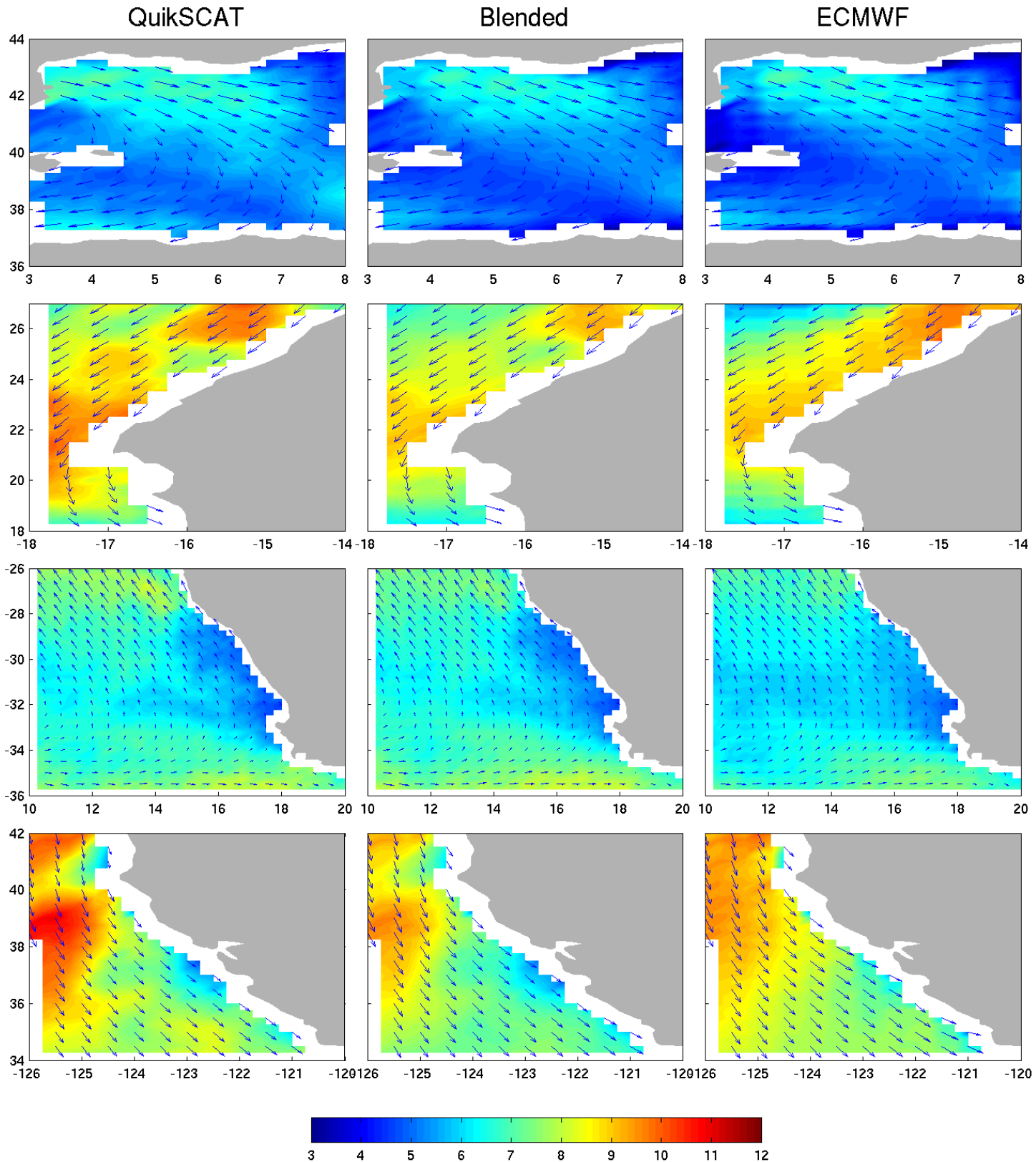

Figure 7 : As Figure 5 for July 2005 